\title{
Scheduling Drip Irrigation for Agricultural Crops using Intelligent Irrigation System
}

\author{
Mohamed. M. Shaglouf* \\ Electrical Dept, Faculty of \\ Engineering, Sirt University, \\ Libya
}

\author{
Mostafa. A. Benzaghta \\ General Dept, Faculty of \\ Agriculture, Misurata \\ University, Libya \\ shaglof@su.edu.ly
}

\author{
Moftah. A. Abusta \\ Electrical Dept, Faculty \\ of Engineering, Sirt \\ University, Libya
}

https://doi.org/10.36602/jmuas.2019.v01.01.19

\begin{abstract}
The expansion of agriculture to provide the necessary food is related to the availability of water, but the limited availability of irrigation requires research on techniques to reduce water losses. This paper presents an application of a prototype design of microcontroller based on an intelligent irrigation system which will allow irrigation to take place in the areas. This method can be applied to the system of drip irrigation and its impact on the quantities of water used in irrigation as its application is part of the solution to the problem of water shortage suffered by Libya in addition to reducing the amount of water wasted while irrigating crops. In this study, a network of smart irrigation system was designed for a 5-hectare farm in AL-Sawawa area, located to the east, at about $20 \mathrm{~km}$ from Sirte city. The farm was divided into two parts, a vegetable crops section with an area of 3 ha and the other section of 2 ha for olive trees. The intelligent irrigation system senses the moisture content of the soil and the temperature of the air through the sensors and turns on or off the water pumps using the relays to carry out this procedure. The main advantage of using this irrigation system is to minimize human intervention and ensure proper irrigation. The microcontroller serves as the main unit of the entire irrigation system, Photovoltaic cells are used to provide solar energy as an energy supply for the whole system. The system is controlled by the microcontroller; it obtains data from the sensors, it compares the data as pre-programmed, and the output signals activate the relays to operate the pumps to start the irrigation process.
\end{abstract}

Keywords: irrigation systems-microcontroller- soil moisture- sensor- solar energy. AL-Sawawa

\section{Introduction}

In Libya, the agriculture sector plays a major role in the economy and development of the country. At the present era, farmers have been using conventional techniques in which the farmers irrigate the land at the regular intervals manually. Traditional methods of irrigation always use huge amount of water and causes lower production due to inappropriate amount of water usage in irrigation (Xiao et al., 2010). Drip irrigation, also known as a trickle is a type of modern irrigation system that has the potential to save water and nutrients, where water drips slowly onto the soil through emitters or drippers which are located close to the plants (Turral et al., 2010). The goal is to place water directly into the root zone and minimize evaporation. drip irrigation systems can be more 
efficient than other types of irrigation systems, such as surface or sprinkler, which save up to $66 \%$ of water with the same productivity compared to other systems (Wang, at el, 2000).

Mehmet and Bigak (2002) reported that irrigation water decreased by 1-28\% declare in drip systems compared to a sprinkler system, and nitrogen savings reached up to $43 \%$ with drip irrigation. In order to minimize the water usage and maximize the production rate, there is a need in the residential/commercial irrigation industry for an irrigation controller that responds to soil moisture sensors for conserving water. In the recent years, smart irrigation technologies have been developed. The smart irrigation system is a simple and precise method for country like Libya, it also helps in saving time, reduces the human errors and efforts. The controller should be "user friendly", i.e., easy to program and requiring a minimum number of keys or push-buttons to operate the controller (Al-Ghobari and Mohammad, 2011).

Choice of proper methods is always important in the field of irrigation. Agriculture uses $85 \%$ of available freshwater resources worldwide and this percentage will continue to be dominant in water consumption due to of population growth and increased food demand (Alghariani, 2006). In this era of sensors and technological development there is an urgent need to create strategies based on science and technology for sustainable use of water. In irrigation cost saving technology, labor-saving is the addressing key issues (Kumar et al., 2013). Therefore, the system should be design as low-cost, climate friendly. The objective of this study was to design a prototype intelligent irrigation system for agricultural crops in AL-Sawawa, Sirte city

\section{Literature Survey}

In a few past decades, technology of wireless sensor networks (WSN) has growing rapidly. It has an advantage to the agriculture sector. One of the recent advances in the development of WSN offers new trends like Precision Agriculture (PA) In the proposed system the irrigation controller normalizes the desired moisture level in the agricultural soil by controlling the water flow of the irrigation pump depending on the sensor readings, by switching the pump between ON and OFF states (Haritha and Nallapati,2014).

In the context of global water scarcity, many researches have discussed how the optimization and modernization of irrigation systems can contribute the increase of water productivity (Wolter and Burt ,1996 and Playán and Mateos ,2006). Lamm and Trooien (2003) reported that successful application of subsurface drip irrigation for 10 years in Kansas, USA, reduced the irrigation water-use for corn by 35-55\% compared with traditional forms of irrigation. Modern technological advances have made soil water sensors (SMS) available for efficient and automatic operation of irrigation systems. The automation systems of irrigation based on SMS has the potential to provide maximum 
water-use efficiency (WUE). Such systems are keeping soil moisture in the optimal range for plant growth (Muñoz-Carpena and Dukes 2005). Rane et al, (2015) stated that "the automatic system was tested for 136 days and save $90 \%$ compared with traditional irrigation system".

Controllers of irrigation systems can be classified into two main types open-loop or closed-loop (Kuo and Golnaraghi, 1995). The first type of control systems based on a preset action, which is done with simple irrigation timers. Whereas, closed control loops receive feedback from sensors, make decisions and implement the results of these decisions to the irrigation system (Patil and Desai, 2013).

Many of drawbacks that face irrigation practices solved by adopting intelligent irrigation controllers. This modern control process uses different mathematical models and measures the error between the steady-state-sensed value and the desired value. If error exceeds some given tolerances, then the controller uses an adaptive algorithm that modifies model and control parameters (Al-Ghobari and Mohammad, 2011) The proposed system is based on remote monitoring as well as controlling. Both mobile and computer are monitor and control the drip devices. In smart drip system, an android mobile sends commands to computer to control drip irrigation system, here different sensors like temperature, humidity, light etc. will use for detection purpose. These sensors send the real time values to micro-controller and micro-controller send these values to computer (known as server) via serial communication (Tupe et al., 2015).

\section{Study Area}

The region of Sirte, also known as the 'Surt' region, is an essential Libyan agricultural area situated at a longitude of $31^{\circ} 12^{\prime \prime} 27^{\prime}$, latitude of $16^{\circ} 41^{\prime \prime} 19^{\prime}$ as shown in figure 1 and range between 6 and 30 meters above sea level. It spans $450 \mathrm{~km}$ of the coast. The region consists of over ten agricultural valleys that have been cultivated since the 1970s. The smart drip irrigation system can be applied in any of the previous valleys. However, the system proposed to be sit up in AL-Sawawa as an example. The site consists of around 476 farms plus 483 new farms aged less than two years. The site is located to the east, at about $20 \mathrm{~km}$ from Sirte city.

The site is characterized by an almost flat slope; soil is non-saline, non-alkaline, low fertility, low organic matter, light texture (Sandy loam) and deep profile. Generally, it was classified as Entisols and Aridsols (Abdulaziz, 2008). The chief crops of the study site are cereals, Alfalfa, and wheat; vegetables like potatoes, tomatoes, onions, and lettuce. Several types of trees also grow in the region such as olive, grape, orange and date palm. The climate is characterized by mild winter and warm summer, with minimum average temperature of 6 to $18^{\circ} \mathrm{C}$ and maximum average monthly temperature of 20 $30^{\circ} \mathrm{C}$, and average annual rainfall is less than $180 \mathrm{~mm}$ (Abdulaziz, 2008).

\section{6}

http://www.misuratau.edu.ly/journal/jmuas/

المجلد الأول العدد الأول ديسمبر 2019 


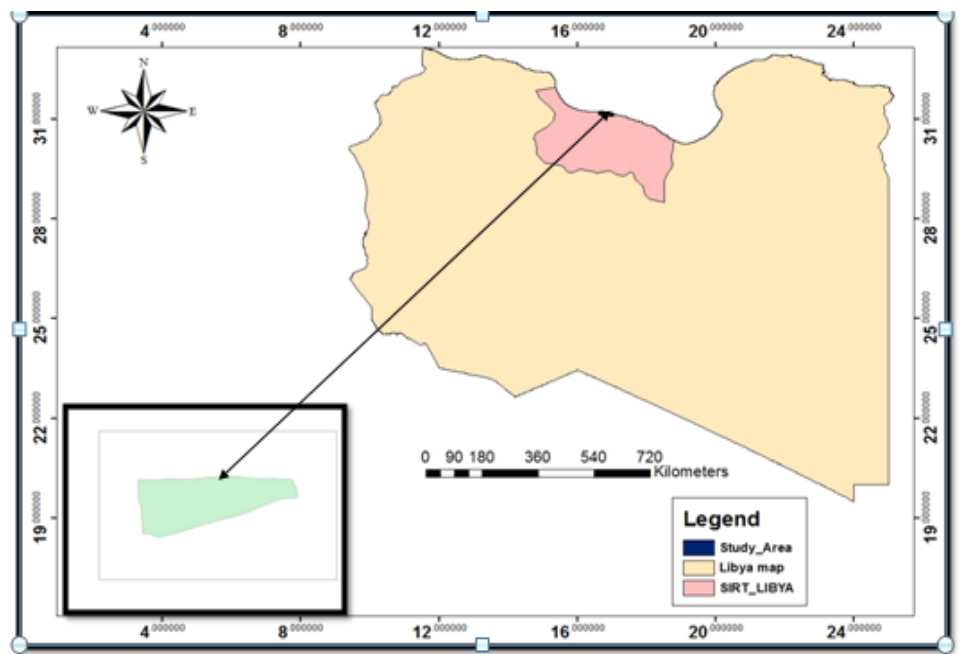

Fig 1. The location of AL-Sawawa area in Sirte city, Libya

\section{Irrigation System}

Irrigation systems can be divided into two main groups: traditional and modern systems. A network of an intelligent drip irrigation system for 5 hectares $(500 \mathrm{~m} \times 100 \mathrm{~m})$ has been designed to be sit up in AL-Sawawa site. The farm was divided into two parts; zone one for vegetable crops (for potatoes) with an area of 3 hectares and the second for trees (for olives) with a total of 2 hectares. In the first zone crops irrigated by GR drippers ( $6 \mathrm{~L} / \mathrm{hr}$.) and the other with bubbles $(45 \mathrm{~L} / \mathrm{hr}$.) for trees. Water in the system flow through a network of pump, valves, pipes, tubing, and emitters and controlled with a complete control system as shown in figure 2 .

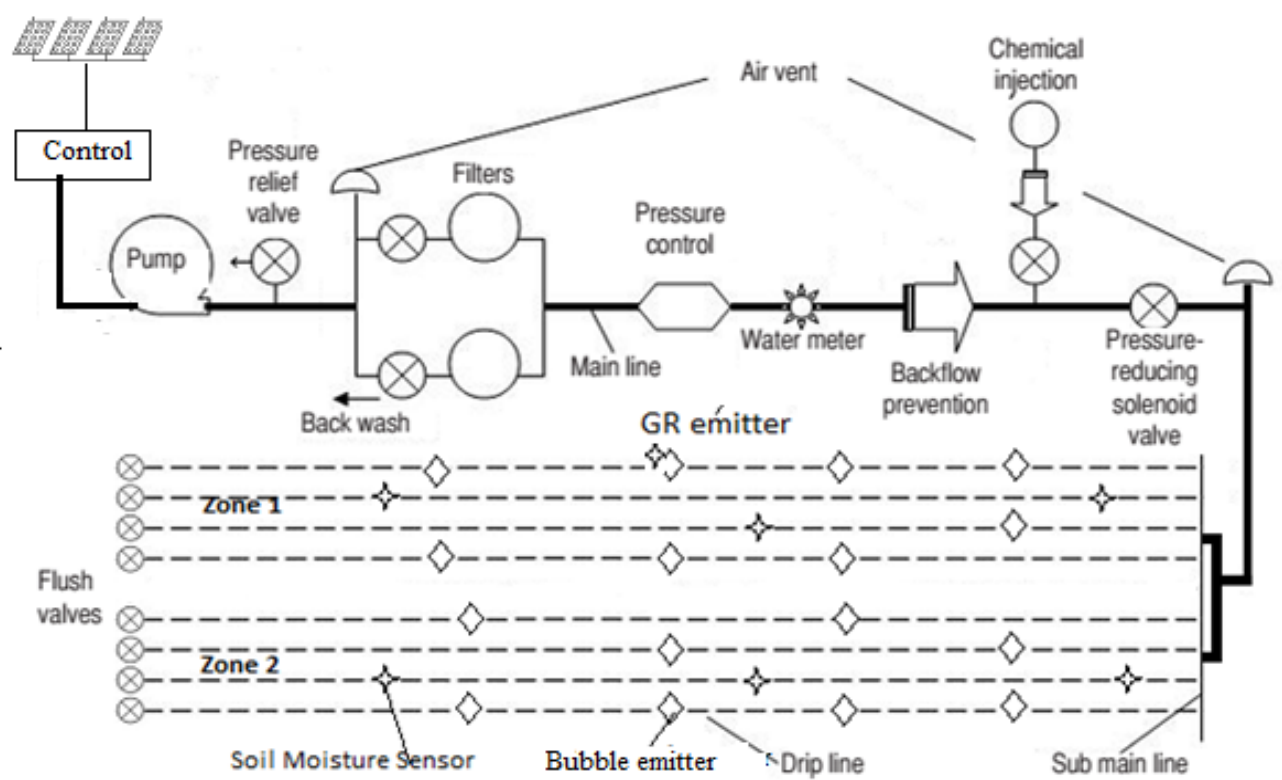

Fig. 2 Layout of irrigation system 


\section{System Architecture}

\section{1- Power Supply System}

\section{1-1 - Solar Radiation in Libya}

Libya is a North African country, with 7 million population distributed over an area of $1,750,000 \mathrm{Km}^{2}$. In the coastal region, the daily average of solar radiation on a horizontal plane is $7.1 \mathrm{kwh} / \mathrm{m}^{2} /$ day, and $8.1 \mathrm{kwh} / \mathrm{m}^{2} /$ day in the southern region, with a sun duration of more than 3500 hours per year. Figure 3 shows a map for the radiation level of Sirte city (Ibrahim, 2006).

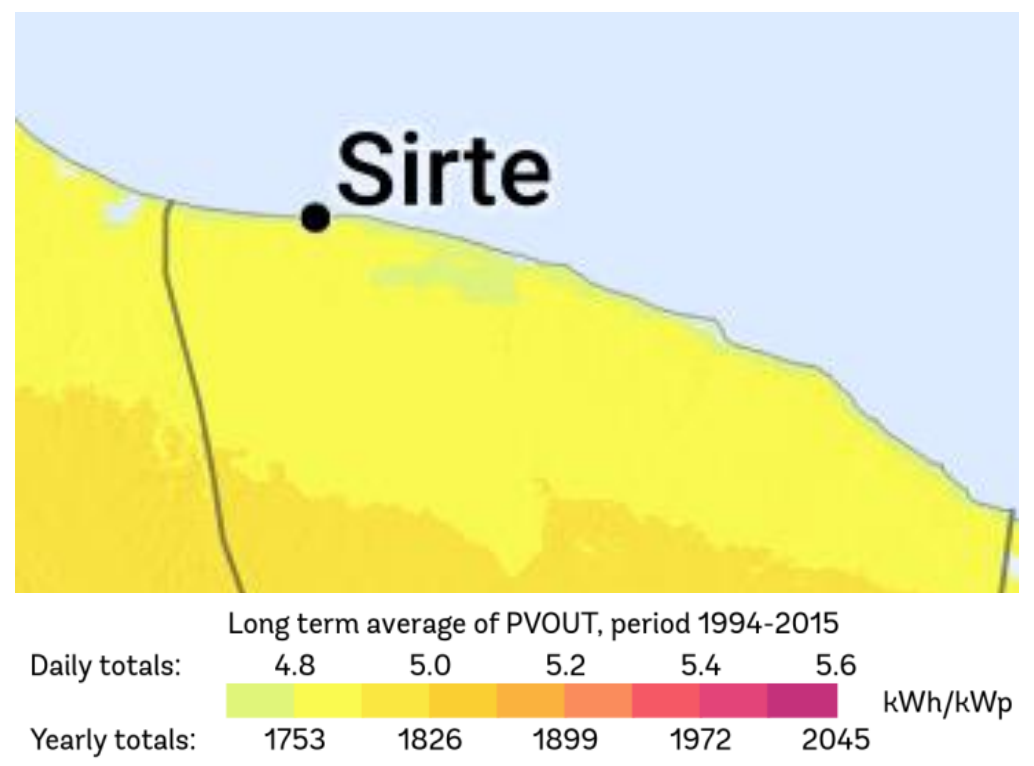

Fig. 3 Map for the radiation level of Sirte city, Libya

\section{1-2- Solar Panel}

A solar cell known as photovoltaic cell, is an electrical device that converts the light of energy directly into electricity via the photovoltaic effect, which is a physical and chemical phenomenon. It is a form of photoelectric cell, defined as a device whose electrical characteristics, such as current, voltage, or resistance, vary when exposed to light. Individual devices of solar cell can be combined to form modules, otherwise recognized as solar panels (Sonal et al., 2018).

Each module is rated by its DC output power under standard test conditions (STC), and typically ranges from 100 to 365 Watts (W). A photovoltaic system typically includes an array of photovoltaic modules, an inverter, a battery pack for storage, interconnection wiring, and optionally a solar mechanism, figure 4 shows the Block Diagram of motor and solar panel connection. 


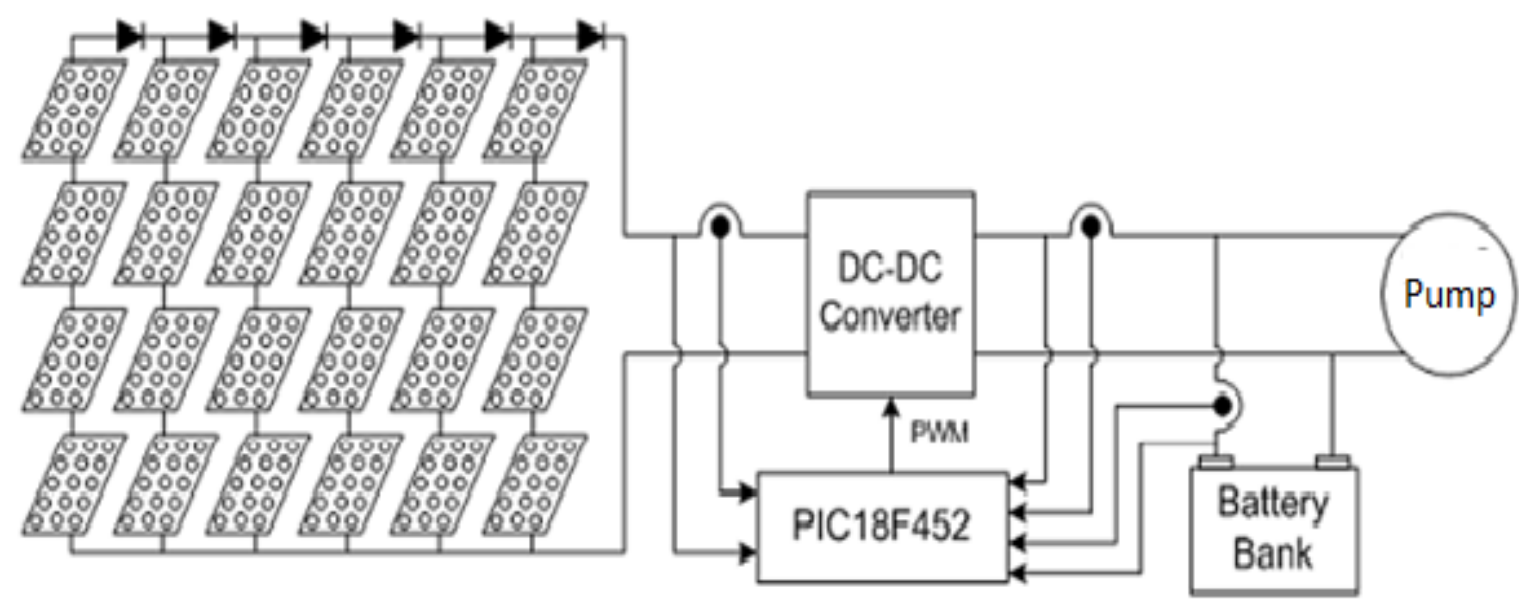

Fig. 4 Block diagram of motor and solar panel connection

\section{1-3 Battery}

Battery is used to store the electricity generated by the solar panels. The system is using batteries of $12 \mathrm{~V}$.

\section{1-4 Voltage Regulator}

7805 is a kind of a voltage regulator integrated circuit. It is one of 78xx series of fixed linear voltage regulator ICs. The source of voltage in a circuit could have fluctuations and would not give the fixed voltage output. The voltage regulator IC maintains the output voltage at a constant value. The $\mathrm{xx}$ in $78 \mathrm{xx}$ indicates the fixed output voltage, it is designed to provide. 7805 provides $+5 \mathrm{~V}$ regulated power supply.

\section{2-1 Description of the Circuit Diagram}

\section{2-1 -1- Microcontroller}

ATmega16 is an 8-bit high performance microcontroller of Atmel's Mega AVR family with low power consumption. Atmega16 is based on enhanced RISC (Reduced Instruction Set Computing) architecture with 131 powerful instructions. Most of the instructions execute in one machine cycle. Atmega16 can work on a maximum frequency of $16 \mathrm{MHz}$. ATmega16 has $16 \mathrm{~KB}$ programmable flash memory, static RAM of $1 \mathrm{~KB}$ and EEPROM of 512 Bytes. The endurance cycle of flash memory and EEPROM is 10,000 and 100,000 , respectively. ATmega16 is a 40 pin microcontroller. There are $32 \mathrm{I} / \mathrm{O}$ (input/output) lines which are divided into four 8-bit ports designated as PORTA, PORTB, PORTC and PORTD. ATmega16 has various in-built peripherals like USART, ADC, Analog Comparator, SPI, JTAG etc. Each I/O pin has an alternative task related to in-built peripherals. the system designed to optimize power consumption versus processing speed (Bhardwaj et al., 2018).

249

http://www.misuratau.edu.ly/journal/jmuas/

المجلد الأول العدد الأول ديسمبر 2019 


\section{2-1 -2 Pin Diagram}

Atmega16 comes with 40 pins where each pin is used to perform a specific task. In total there are $32 \mathrm{I} / \mathrm{O}$ pins and four ports as shown below. Each port consists of $8 \mathrm{I} / \mathrm{O}$ pins. Figure 5 shows the pin diagram.

\begin{tabular}{|c|c|c|c|c|c|c|c|c|}
\hline & (XCK/TO) & PBO & 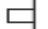 & 1 & 40 & ص & PAO & $(A D C O)$ \\
\hline \multirow{4}{*}{ Pins } & (T1) & PB1 & 미요 & 2 & 39 & 口 & PA1 & (ADC1) \\
\hline & (INT2/AINO) & PB2 & $\square$ & 3 & 38 & $\sqsupseteq$ & PA2 & $(A D C 2)$ \\
\hline & (OCO/AIN1) & PB3 & $\square$ & 4 & 37 & $\sqsupseteq$ & PA3 & (ADC3) \\
\hline & (SS) & PB4 & 만 & 5 & 36 & 曰 & PA4 & (ADC4) \\
\hline \multirow{6}{*}{ Pins } & (MOSI) & PB5 & 口 & 6 & 35 & $\sqsupseteq$ & PA5 & (ADC5) \\
\hline & (MISO) & PB6 & $\square$ & 7 & 34 & $\sqsupseteq$ & PA6 & (ADC6) \\
\hline & $(\mathrm{SCK})$ & PB7 & ㅁ & 8 & 33 & 口 & PA7 & (ADC7) \\
\hline & RE & ESET & 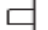 & 9 & 32 & 口 & AREF & \\
\hline & & VCC & 마 & 10 & 31 & 尸 & GND & \\
\hline & & GND & 마 & 11 & 30 & $\sqsupseteq$ & AVCC & \\
\hline \multirow{6}{*}{ 29) } & & TAL2 & $\square$ & 12 & 29 & $\sqsupseteq$ & PC7 & (TOSC2) \\
\hline & & TAL1 & $\square$ & 13 & 28 & 口 & PC6 & (TOSC1) \\
\hline & $(R \times D)$ & PDO & 무 & 14 & 27 & 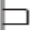 & PC5 & (TDI) \\
\hline & $(T \times D)$ & PD1 & 마 & 15 & 26 & $\sqsupseteq$ & PC4 & (TDO) \\
\hline & (INTO) & PD2 & 마 & 16 & 25 & 口 & PC3 & (TMS) \\
\hline & (INT1) & PD3 & 막 r r & 17 & 24 & $\sqsupseteq$ & PC2 & (TCK) \\
\hline \multirow{3}{*}{ 21) } & (OC1B) & PD4 & 마 & 18 & 23 & 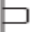 & PC1 & (SDA) \\
\hline & (OC1A) & PD5 & $\square$ & 19 & 22 & $\sqsupseteq$ & PCO & (SCL) \\
\hline & (ICP1) & PD6 & 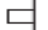 & 20 & 21 & $\square$ & PD7 & (OC2) \\
\hline
\end{tabular}

- PORTA $=8$

(Pin $33-40)$

- $\mathrm{PORTB}=8$

(Pin $1-8)$

- PORTC $=8$

Pins (Pin $22-$

- $\quad$ PORTD $=8$

Pins (Pin 14 -

Fig. 5 The pin diagram

\section{2-1 -3 Soil Moisture Sensor}

Most sensors of soil moisture are designed to estimate the content of soil water as volumetric depending on the dielectric constant (soil bulk permittivity) of the soil. The two large exposed pads function as probes for the sensor, together acting as a variable resistor. The extra amount of water in the soil means that the better the conductivity between the pads will be and will result in a lower resistance (Kumar et al., 2013). The sensor is placed in the field where the crop is being cultivated (root zone). It is switch on/off recording to the available water percentage (in volume) as shown in table 1.

Table (1) Relationship between soil texture and soil moisture constant

\begin{tabular}{|c|c|c|c|}
\hline Soil Texture & $\begin{array}{c}\text { Permanent Wilting } \\
\text { Point (\%) }\end{array}$ & $\begin{array}{c}\text { Filed Capacity } \\
(\%)\end{array}$ & $\begin{array}{c}\text { Available Water } \\
(\%)\end{array}$ \\
\hline Sandy & $2-6$ & $6-12$ & $4-6$ \\
Average & $(4)$ & $(9)$ & $(5)$ \\
\hline Sandy loam & $4-8$ & $10-18$ & $6-10$ \\
Average & $(6)$ & $(9)$ & $(8)$ \\
\hline Loam & $8-12$ & $18-26$ & $10-14$ \\
Average & $(10)$ & $(22)$ & $(12)$ \\
\hline Clay loam & $11-15$ & $23-31$ & $12-16$ \\
Average & $(13)$ & $(27)$ & $(14)$ \\
\hline Silty Clay & $12-17$ & $27-35$ & $14-18$ \\
Average & $(15)$ & $(31)$ & $(16)$ \\
\hline Clay & $15-19$ & $31-39$ & $18-20$ \\
Average & $(17)$ & $(35)$ & $(18)$ \\
\hline
\end{tabular}




\section{2-1-4 Temperature Sensor (LM35)}

Temperature sensor (LM35) is a precision IC temperature sensor with its output proportional to the temperature (in $\mathrm{C}^{0}$ ). The sensor circuitry is sealed and therefore it is not subjected to oxidation and other processes. With LM35, temperature can be measured more accurately than with a thermistor. It also possesses low self-heating and does not cause more than $0.1 \mathrm{C}^{0}$ temperature rise in still air. The operating temperature range is from $-55^{\circ} \mathrm{C}$ to $150^{\circ} \mathrm{C}$. The output voltage varies by $10 \mathrm{mV}$ in response to every $\mathrm{C}^{\circ}$ rise/fall in ambient temperature, i.e., its scale factor is $0.01 \mathrm{~V}^{\prime} \mathrm{C}^{\mathrm{o}}$ (Soloman,2009).

\section{2-1-5 LCD}

LCD is an electronic display module which uses liquid crystal to produce a visible image. The $16 \times 2$ LCD display is a very basic module commonly used for displaying alphabets and numeric value. A 16X2 LCD has two registers namely, command and data. The register select is used to switch from one register to other. $\mathrm{RS}=0$ for command register, whereas $\mathrm{RS}=1$ for data register. The command register stores the command instructions given to the LCD. A command is an instruction given to LCD to do a predefined task like initializing it, clearing its screen, setting the cursor position, controlling display etc. The data register stores the data to be displayed on the LCD. The data is the ASCII value of the character to be displayed on the $\operatorname{LCD}($ Soloman,2009).

\section{2-1-6 Relays}

Relays are switching that open and close circuits electromechanically or electronically. Relays control one electrical circuit by opening and closing contacts in another circuit. Relays are generally used to switch smaller currents in a control circuit and do not usually control power consuming devices except for small motors and Solenoids that draw low amps Nonetheless, relays can "control" larger voltages and amperes by having an amplifying effect because a small voltage applied to a relays coil can result in a large voltage being switched by the contacts. The main operation of a relay comes in places where only a low-power signal can be used to control a circuit. It is also used in places where only one signal can be used to control a lot of circuits (Soloman,2009).

\section{2-2 Working of the System}

In the field of agriculture, use of proper method of irrigation is important. The advantage of using this method is to reduce human intervention and still ensure proper irrigation. This paper focuses on design of an automatic irrigation system in AL-Sawawa, Sirte, which switches the motor pump on/off on sensing the moisture content of the soil and monitors the real time temperature of the farm. In this system the moisture sensor, temperature sensor, LCD, and motor pump are interfaced with atmega16. Moisture sensor and temperature sensor provides analog signal to atmega16 microcontroller. 
Microcontroller needs to convert this analog signal into digital value. The atmega16 has an inbuilt 8 channel, 10 bit analog to digital converter. Here, the system will first convert a $5 \mathrm{~V}$ signal and then a $0 \mathrm{~V}$ signal with a reference voltage of $5 \mathrm{~V}$ of ADC. After each conversion, the analog to digital converter of atmegal 6 will give a 10-bit value for each signal $(5 \mathrm{~V}$ and $0 \mathrm{~V})$. These outputs of the analog to digital converter are displayed in a $2 \times 8 \mathrm{LCD}$ array. When a $5 \mathrm{~V}$ signal is converted, the output of analog to digital converter is $0 \times 3 \mathrm{ff}(1023)$ and when $0 \mathrm{~V}$ signal is converted, the output is $0 \times 00(0)$.

The status of the water pump, soil moisture and temperature is displayed on the LCD, which is interfaced to the microcontroller. Thus, this automatic irrigation system depends on the output of the moisture sensor. When the moisture sensor senses the soil moisture content is at maximum allowable depletion then the microcontroller turn ON the motor pump and if moisture sensor senses the soil is at the filed capacity then microcontroller turn OFF the motor pump.

\section{Conclusions}

Improving irrigation efficiency can contribute greatly to reducing production cost of crops, making the demand supply response more efficient. Recent technological advances have made soil water sensors available for efficient and automatic operation of irrigation systems. It can hereby see that the irrigation controlling system which is extremely user friendly because it requires very less human interference for it operations once it is manufactured and implemented. This intelligent irrigation system can be applied in Sirte farms without suffering from the negative effects on productions. In a word, it not only saves the most precious gift of the nature, i.e., water, it also helps the farmers to grow their crops under controlled conditions and under continuous observation by SMS and temperature monitoring. Hence, this study should be applied to help in increase and good quality productions.

\section{References}

Abdulaziz, M. (2008). Land assessment for agriculture development in the great manmade river projects. Case study: Sirte and Benghazi. Twelfth International Water Technology Conference, IWTC12, Alexandria, Egypt.

Alghariani, S. (2006) Reduce agricultural water demand in Libya through the improvement of water efficiency and crop water productivity. International Center for Agriculture Research in Dry Areas (ICARDA). 
Al-Ghobari, H.M. and Mohammad, F.S. (2011). Intelligent irrigation performance: evaluation and quantifying its ability for conserving water in arid region. Applied Water Science, 1(3-4): p.73-83.

Bhardwaj,S,. Goel, S, Sanga, V. and Y. Bhasker. (2108). Automatic Irrigation System with Temperature Monitoring. International Research Journal of Engineering and Technology (IRJET), 5 (2).

Haritha, T and Nallapati, S. (2014). Intelligent Irrigation Control System. International Journal of Electronics and Communication Engineering (SSRG-IJECE) India, 1 (10).

Ibrahim S. (2006). Prospects of renewable energy in Libya. Al-Fateh University, Tripoli. International Symposium on Solar Physics and Solar Eclipses (SPSE): p 153-161.

Kumar, N.D., Pramod, S. and C, Sravani. (2013). Intelligent irrigation system. International Journal of Agricultural Science and Research (IJASR), 3(3): p.23-30.

Kuo, B.C. and Golnaraghi, F. (1995). Automatic control systems (Vol.9). Englewood Cliffs, NJ: Prentice-Hall., London.

Lamm, F. R., and Trooien, T. P. (2003). Subsurface drip irrigation for corn production: a review of 10 years of research in Kansas. Irrigation science, 22(3-4): p 195-200.

Mehmet, Q, and H. Bigak,(ed.). (2002). Modern and Traditional Irrigation Technologies in the Eastern Mediterranean, Ottawa, Canada: The International Development Research Centre.

Muñoz-Carpena R and Dukes MD. (2005). Automatic irrigation based on soil moisture for vegetable crops IFAS extension. University of Florida.

Patil, P. and Desai, B.L., (2013). Intelligent irrigation control system by employing wireless sensor networks. International Journal of Computer Applications, 79(11).

Playán, E. and Mateos, L. (2006). Modernization and optimization of irrigation systems to increase water productivity. Agricultural water management, 80(1-3): p.100-116.

Rane, D., Indurkar, P.R. and D.M. Khatri,.(2015). Review paper based on automatic irrigation system based on RF module. IJAICT, 1(9): p.736-738.

Shock, C. C. (2006). Drip irrigation: an introduction. Oregon State University.

Smajstrla, A.G. and Locascio, S.J. (1996). Tensiometer-controlled, drip-irrigation scheduling of tomato. Applied Engineering in Agriculture, 12(3): p.315-319.

Soloman, S. (2009). Sensors handbook. McGraw-Hill, Inc.

253

http://www.misuratau.edu.ly/journal/jmuas/ 2019 المجلد الأول العدد الأول ديسمبر 
Sonal D, Ankush S., and S. Shyamkumar. (2018). A Review on Solar Based Plant Irrigation System. International Research Journal of Engineering and Technology (IRJET), 5 (2).

Tupe, R., Gaikwad, P and K. Sonali. (2015). Intelligent Drip Irrigation System International Journal of Innovative Research in Advanced Engineering (IJIRAE) ISSN, 2 (2): P.2349-2163.

Turral, H., S. Mark and F. Jean. (2010). Investing in irrigation: Reviewing the past and looking to the future. Agricultural Water Management 97(4): p.551-560.

Wang, D., Shannon, M. C., Grieve, C. M., and Yates, S. R. (2000). Soil water and temperature regimes in drip and sprinkler irrigation, and implications to soybean emergence. Agricultural Water Management, 43(1): p.15-28.

Wolter, HW and Burt, CM. (1996). Concepts for irrigation system modernization. In: Proceedings of the expert consultation on modernization of irrigation schemes: past experiences and future options. Food and Agricultural Organization of the United Nations. Bangkok, Thailand.

Xiao, K., Xiao, D., and X. Luo. (2010). Smart water-saving irrigation system in precision agriculture based on wireless sensor network. Transactions of the Chinese society of Agricultural Engineering, 26(11): p.170-175. 


\title{
جدولة الري بالتنقيط للمحاصيل الزراعية باستخدام نظام ري ذكي
}

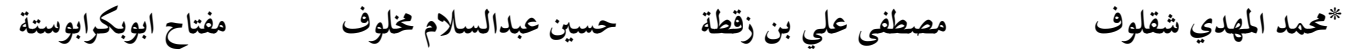 \\ قسم الهندسة الكهربائية ، كلية الهندسة، القسم العام ، كلية الزراعة، قسم التربة والمياه ، كلية الزراعة، قسم الهندسة الكهربائية، كلية

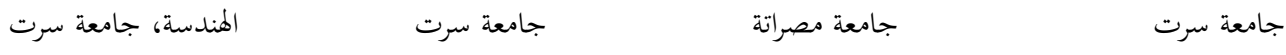 \\ shaglouf@su.edu.ly
}

https://doi.org/10.36602/jmuas.2019.v01.01.19

يعد التوسع في الزراعة لتأمين الغداء اللازم مرتبطاً بتوفر مياه الري، إلا أن محدودية مصادر مياه الري يستوجب البحث عن تقنيات جديدة لتقليل الفاقد من هذه المياه، تمدف هذه الدراسة لتصميم برنامج نظام ري يعمل بالطاقة الشمسية يتسم بكونه صديقا للبيئة وذا تكلفة منخفضة، يمكن تطبيق هذا النظام على الري بالتنقيط وبيان أثره على كميات المياه المستخدمة في الري إذ يعد تطبيق هذا البرنامج جزءا من الحل لمشكلة نقص المياه التي تعانيها ليبيا بالإضافة الى تقليل كميات المياه التي تمدر أثناء ري المحاصيل الزراعية. في هذه الدراسة تم تصميم شبكة من نظام الري الذكي لمزرعة مساحتها 5 هكتار، تم تقسيم المزرعة إلى قسمين، قسم ملماصيل الخضروات بمساحة 3 هكتار والقسم الآخر بمساحة 2 هكتار لأشجار الزيتون، يقوم نظام الري الذكي باستشعار محتوى رطوبة التربة ودرجة حرارة الجو عن طريق حساسات الرطوبة ودرجة الحرارة ويعمل على تشغيل أو إيقاف مضخات المياه باستخدام المرحلات لتنفيذ هذا الإجراء، الميزة الرئيسية لاستخدام نظام الري هذا هي تقليل تدخل الإنسان وضمان الري المناسب، يعمل المتحكم الدقيق كوحدة رئيسية لنظام الري بأكمله، ويتم استخدام الخلايا الكهروضوئية لتوفير الطاقة الشمسية كمزود للطاقة لتزويد النظام بأكمله، ويتم التحكم في النظام بواسطة المتحكم الدقيق حيث أنه بمجرد أن يكصل المتحكم الدقيق على البيانات من مجسات الاستشعار فإنه يقارن البيانات كما هي مبرججة مسبقا مما يولد إشارات الخرج وينشط المرحلات لتشغيل المضخات لبدء عملية الري.

الكلمات المفتاحية: نظم الري، المتحكم الدقيق، رطوبة التربة، حساس، الطاقة الشمسية. 